\title{
Influence of Graded Levels of Nitrogen and Potassium Combinations on the Flower Yield of Annual Chrysanthemum (Chrysanthemum coronarium L.)
}

\author{
P. Ravi Teja, V. Vijaya Bhaskar" and P. Subbaramamma
}

Horticultural College and Research Institute, Dr. YSR Horticultural University, Venkataramannagudem - 534 101, West Godavari district, Andhra Pradesh, India

*Corresponding author

\section{A B S T R A C T}

\begin{tabular}{|c|c|}
\hline Keywords & n investigation was carried out at $\mathrm{Ho}$ \\
\hline $\begin{array}{l}\text { Annual } \\
\text { chrysanthemum, } \\
\text { Nitrogen, Potassium, } \\
\text { Partitioning, Flower } \\
\text { yield. }\end{array}$ & $\begin{array}{l}16 \text { to evaluate the influence of graded levels of nitrogen and potassium combinations on } \\
\text { the flower yield of annual chrysanthemum. The study has revealed that significantly } \\
\text { highest number of flowers per plant }(28.00) \text {, highest flower diameter }(7.83 \mathrm{~cm}) \text { and highest } \\
\text { flower yield per hectare }(25.25 \text { q) were observed by application of nitrogen at the rate of }\end{array}$ \\
\hline Arti & \\
\hline $\begin{array}{l}\text { Accepted: } \\
\text { 10 September } 2017 \\
\text { Available Online: } \\
10 \text { October } 2017\end{array}$ & $\begin{array}{l}\text { xperiment when compared with the application of nutrients before the experimentation. } \\
\text { he maximum utility level of the nitrogen and potassium contents by the plant was } \\
\text { bserved by application of nitrogen and potassium respectively at the rate of } 200 \text { and } 150 \\
\mathrm{~g} \mathrm{ha}^{-1} \text {. }\end{array}$ \\
\hline
\end{tabular}

\section{Introduction}

Annual chrysanthemum (Chrysanthemum coronarium L.) is considered to be one of the most important cultivated commercial flower crop grown all over India. The species is also referred to as Leucanthemum coronarium or Glebionis coronarium. It is a winter season annual and propagated through seeds. It produces white and yellow coloured blooms and generally used in garland making as well as bedding material in the landscape gardens. The flowers are generally used for making garlands, veni and also used in the floral decorations during social and religious functions. Annual chrysanthemum is different from the regular chrysanthemum in many aspects. The crop has relatively short duration and photo insensitive. Under moderate climatic conditions flowering is observed almost throughout the year. The plant is considered to be hardier, vigorous and grows taller. Flowers are generally edible, however, center core of the flower is bitter in taste. Petals are used either in fresh or in dried state to garnish or to brew a tea. In some countries, young leaves and seedlings are used as vegetable. The small leaf types are very strong in taste and are often eaten as cooked or in fried form together with other vegetables and also used in making soups. The large leaf types can be eaten as raw in salads. Young leaves and stems are used in flavoring the soups. The leaves are important ingredients in 
Taiwanese Oyster omelettes. Young shoots and stems are eaten as raw or in the cooked form as the plant is considered to possess several medicinal properties. However, cultivation of crop is limited to certain pockets of moderate climatic zones and the nutrient requirement of the crop is not standardized in many parts of the cultivated areas. In general, application of major nutrients viz., nitrogen, phosphorous and potassium play an important role in enhancing the vegetative growth and development of many flower crops there by increased the flower yield. Based on the available literature, it is evident that very little research work has been carried out so far on the vegetative and floral responses of annual chrysanthemum to nitrogen, phosphorus and potassium application in many parts of the country especially in the coastal regions. Keeping all these things in view, the present investigation was planned to study the influence of graded levels of nitrogen and potassium combinations on the flower yield of annual chrysanthemum and elucidation of partitioning of these nutrients to different parts of the plant in enhancing the flower yield.

\section{Materials and Methods}

The present investigation was carried out at Horticultural College and Research Institute, Venkataramannagudem, West Godavari district of Andhra Pradesh during the year 2015-2016. The experimental area had a medium red soil and sandy loam in texture with moderate fertility. Soil samples were collected at random prior to preparatory cultivation at about 0 to $30 \mathrm{~cm}$ depth from the experimental field and a composite sample was analyzed for physico-chemical properties of the soil by adopting standard methods (Table 1). In the experimentation, there were about 16 treatments consisting of 4 levels each of nitrogen viz., $\mathrm{N}_{1}\left(50 \mathrm{~kg} \mathrm{ha}^{-1}\right), \mathrm{N}_{2}(100$ $\left.\mathrm{kg} \mathrm{ha}{ }^{-1}\right), \mathrm{N}_{3}\left(150 \mathrm{~kg} \mathrm{ha}^{-1}\right), \mathrm{N}_{4}\left(200 \mathrm{~kg} \mathrm{ha}^{-1}\right)$ and potassium $\mathrm{K}_{1}\left(50 \mathrm{~kg} \mathrm{ha}^{-1}\right), \mathrm{K}_{2}\left(100 \mathrm{~kg} \mathrm{ha}^{-1}\right)$, $\mathrm{K}_{3}\left(150 \mathrm{~kg} \mathrm{ha}^{-1}\right), \mathrm{K}_{4}\left(200 \mathrm{~kg} \mathrm{ha}^{-1}\right)$ with a recommended uniform dose of phosphorus $\left(100 \mathrm{~kg} \mathrm{ha}^{-1}\right)$ application to all the treatments. A recommended dose of FYM was also applied to all the treatments uniformly. The experiment was laid out in a factorial randomized block design with three replications. The gross plot size was $2.5 \times 2.5$ $\mathrm{m}^{2}$ and the net plot size was $2.25 \times 2.25 \mathrm{~m}^{2}$. The spacing adopted was $40 \mathrm{~cm}$ between the rows and plants within a row. The straight fertilizers viz., Urea, Single Super Phosphate and Muriate of Potash were used as the source of $\mathrm{N}, \mathrm{P}_{2} \mathrm{O}_{5}$ and $\mathrm{K}_{2} \mathrm{O}$ respectively. Entire dose of phosphorus was applied as a basal dose and the graded doses of nitrogen and potassium were applied in two split doses at 30 and 60 days after planting as per the treatments fixed. Estimation of nutrient status in the soil and plant samples was done in the laboratory by adopting the standard procedures established by several research workers. Available organic carbon in the soil (Walkley and Black, 1947), nitrogen content in the soil and plant samples was estimated by Microkjeldahl's method described by Tandon (1993), phosphorous content in the soil and plant samples was estimated by vando molbdo phosphoric acid yellow colour method described by Tandon (1993), potassium content in the soil and plant samples was estimated by flame photometric method described by Jackson (1973). Yield parameters viz., number of flowers per plant, flower diameter and flower yield per hectare were recorded as per the standard procedures outlined by different research workers. The data collected on each character was subjected to statistical analysis by ANOVA technique as described by Panse and Sukhatme (1967). The treatment means were compared by using the least significant difference values calculated at 5 per cent level of significance. 


\section{Results and Discussion}

The data pertaining to available organic carbon content in the soil planted with annual chrysanthemum was found non-significant with respect to the individual and interaction effects of nitrogen and potassium contents in the soil after harvest of the flowers (Table 2). Further, it may be noticed from the results that an increase in the quantity of application of nitrogen and potassium in any combination has showed no significant effect on the per cent of organic carbon available in the soil when compared with the available organic carbon content in the soil before experimentation (Table. 1) and remained without any significant differences among the treatment combinations.

The data pertaining to available nitrogen content in the soil after harvest of annual chrysanthemum was found significant with respect to the individual and interaction effects of nitrogen and potassium (Table 2). Application of nitrogen at the rate of $50 \mathrm{~kg} \mathrm{ha}^{-1}$ recorded significantly lowest nitrogen content in the soil after harvest (132.50), whereas, significantly highest nitrogen content in the soil after harvest (163.50) was observed with the application of nitrogen at the rate of 200 $\mathrm{kg} \mathrm{ha}^{-1}$ followed by application of nitrogen at the rate of $150 \mathrm{~kg} \mathrm{ha}^{-1}$.

Application of potassium at the rate of $50 \mathrm{~kg}$ $\mathrm{ha}^{-1}$ recorded significantly lowest nitrogen content in the soil after harvest (142.25) followed by application of potassium at the rate of $100 \mathrm{~kg} \mathrm{ha}^{-1}$, whereas, significantly highest nitrogen content in the soil after harvest (150.50) was observed by application of potassium at the rate of $200 \mathrm{~kg} \mathrm{ha}^{-1}$ followed by application of potassium at the rate of $150 \mathrm{~kg} \mathrm{ha}^{-1}$. Significant differences were observed in the interaction effect of nitrogen and potassium application in the soil with respect to nitrogen content available in the soil after harvest. Significantly lowest nitrogen content in the soil after harvest (129.00) was observed by application of nitrogen and potassium each at the rate of 50 $\mathrm{kg} \mathrm{ha}{ }^{-1}$, whereas, significantly highest nitrogen content in the soil after harvest (168.00) was observed by application of nitrogen and potassium each at the rate of 200 $\mathrm{kg} \mathrm{ha}^{-1}$. Based on the results obtained, it may be concluded that the plant has inherent capacity to utilize the possible highest dose of nitrogen applied $\left(200 \mathrm{~kg} \mathrm{ha}^{-1}\right)$ and further required quantity from the soil for increasing the production of flowers.

The data pertaining to available phosphorus content in the soil after harvest of annual chrysanthemum was observed non-significant with respect to the individual and interaction effects of nitrogen and potassium (Table 3). The results obtained have indicated that available phosphorus content in the soil after harvest was not found significant with any of the individual or combination of nitrogen and potassium treatments. The reason might be due to application of recommended dose of phosphorous to all the treatment plots uniformly.

The data pertaining to available potassium content in the soil after harvest of annual chrysanthemum was (Table 3) found significant with respect to the individual and interaction effects of nitrogen and potassium. Application of nitrogen at the rate of $50 \mathrm{~kg} \mathrm{ha}^{-1}$ recorded significantly lowest potassium content in the soil after harvest (150.00), whereas, significantly highest potassium content in the soil after harvest (203.50) was observed with the application of nitrogen at the rate of $200 \mathrm{~kg} \mathrm{ha}^{-1}$. Application of potassium at the rate of $50 \mathrm{~kg} \mathrm{ha}^{-1}$ recorded significantly lowest potassium content in the soil after harvest (170.50), whereas, significantly highest potassium content in the soil after harvest (180.75) was observed by 
application of potassium at the rate of $200 \mathrm{~kg}$ $\mathrm{ha}^{-1}$ followed by the application of potassium at the rate of $150 \mathrm{~kg} \mathrm{ha}^{-1}$. Significant differences were observed in the inter action effect of nitrogen and potassium with respect to the available potassium content in the soil after harvest. Significantly lowest potassium content in the soil after harvest (144.00) was observed by application of nitrogen and potassium each at the rate of $50 \mathrm{~kg} \mathrm{ha}^{-1}$, whereas, significantly highest potassium content in the soil after harvest (208.00) was observed by application of nitrogen and potassium each at the rate of $200 \mathrm{~kg} \mathrm{ha}^{-1}$. Based on the results obtained it may be concluded that significant differences were observed in the available nitrogen and potassium contents in the soil after harvest by application of graded levels of nitrogen and potassium in different combinations. Available nitrogen and potassium content in the soil has increased with an increase in the level of nitrogen and potassium applied due to an increase in the fixation of nitrogen and potassium in the soil. Similar kind of high residual nutrient values after harvesting the crop was observed earlier by Chandana et al., (2014) and Chouhan et al., (2014) in gladiolus. The reason might be due to their corresponding higher doses.

Table.1 Physico-chemical properties of soil sample at the experimental site before experimentation

\begin{tabular}{|c|c|c|c|}
\hline S. No. & Properties & $\begin{array}{l}\text { Value } \\
\text { obtained }\end{array}$ & Method adopted \\
\hline $\begin{array}{l}\text { I. } \\
\text { a. }\end{array}$ & $\begin{array}{l}\text { Physical properties: } \\
\text { Particle size analysis } \\
\text { Sand (\%) } \\
\text { Silt (\%) } \\
\text { Clay (\%) }\end{array}$ & $\begin{array}{l}70 \% \\
20 \% \\
10 \%\end{array}$ & $\begin{array}{l}\text { International pipette method (Piper, } \\
\text { 1966) }\end{array}$ \\
\hline $\begin{array}{l}\text { II. } \\
\text { a. }\end{array}$ & $\begin{array}{l}\text { Chemical properties: } \\
\text { Available Nitrogen }\end{array}$ & $190 \mathrm{~kg} \mathrm{ha}^{-1}$ & $\begin{array}{l}\text { Modified Kjeldahl method (Jackson, } \\
\text { 1973) }\end{array}$ \\
\hline b. & Available $\mathrm{P}_{2} \mathrm{O}_{5}$ & $34.5 \mathrm{~kg} \mathrm{ha}^{-1}$ & Olsen's method (Jackson, 1967) \\
\hline c. & Available $\mathrm{K}_{2} \mathrm{O}$ & $225 \mathrm{~kg} \mathrm{ha}^{-1}$ & Flame Photometry (Jackson, 1973) \\
\hline d. & Soil pH & 6.57 & Potentiometry (Piper, 1966) \\
\hline e. & Electrical conductivity & $0.2 \mathrm{dS} \mathrm{m}^{-1}$ & Conductivity bridge (Jackson, 1967) \\
\hline f. & Organic carbon & $0.26 \%$ & $\begin{array}{l}\text { Wet oxidation method (Walkley and } \\
\text { Black, 1947) }\end{array}$ \\
\hline
\end{tabular}


Table.2 Estimation of available organic carbon and nitrogen in the soil after harvesting of annual chrysanthemum

\begin{tabular}{|c|c|c|c|c|c|c|c|c|c|c|}
\hline \multirow{3}{*}{ Treatments } & \multicolumn{10}{|c|}{ Organic carbon and nitrogen in the soil after harvesting } \\
\hline & \multicolumn{5}{|c|}{ Organic carbon $(\%)$} & \multicolumn{5}{|c|}{ Nitrogen $\left(\mathrm{kg} \mathrm{ha}^{-1}\right)$} \\
\hline & $\mathbf{K}_{\mathbf{5 0}}$ & $\mathbf{K}_{100}$ & $\mathbf{K}_{\mathbf{1 5 0}}$ & $\mathbf{K}_{\mathbf{2 0 0}}$ & Mean & $\mathbf{K}_{\mathbf{5 0}}$ & $\mathbf{K}_{\mathbf{1 0 0}}$ & $\mathbf{K}_{\mathbf{1 5 0}}$ & $\mathbf{K}_{\mathbf{2 0 0}}$ & Mean \\
\hline $\mathbf{N}_{50}$ & 0.15 & 0.19 & 0.20 & 0.22 & 0.19 & 129.00 & 132.00 & 134.00 & 135.00 & 132.50 \\
\hline $\mathbf{N}_{100}$ & 0.19 & 0.23 & 0.24 & 0.26 & 0.23 & 136.00 & 138.00 & 140.00 & 145.00 & 139.75 \\
\hline $\mathbf{N}_{150}$ & 0.22 & 0.25 & 0.26 & 0.28 & 0.25 & 148.00 & 149.00 & 150.00 & 154.00 & 150.25 \\
\hline $\mathbf{N}_{200}$ & 0.24 & 0.27 & 0.28 & 0.31 & 0.28 & 160.00 & 164.00 & 166.00 & 168.00 & 163.50 \\
\hline \multirow[t]{2}{*}{ Mean } & 0.20 & 0.24 & 0.25 & 0.28 & 0.24 & 142.25 & 145.75 & 147.50 & 150.50 & 146.50 \\
\hline & \multicolumn{3}{|c|}{ SEm \pm} & \multicolumn{2}{|c|}{ CD at $5 \%$} & \multicolumn{3}{|c|}{ SEm \pm} & \multicolumn{2}{|c|}{ CD at $5 \%$} \\
\hline $\mathbf{N}$ & \multicolumn{3}{|c|}{0.01} & \multicolumn{2}{|c|}{0.02} & \multicolumn{3}{|c|}{0.38} & \multicolumn{2}{|c|}{1.12} \\
\hline $\mathbf{K}$ & \multicolumn{3}{|c|}{0.01} & \multicolumn{2}{|c|}{0.02} & \multicolumn{3}{|c|}{0.38} & \multicolumn{2}{|c|}{1.12} \\
\hline $\mathbf{N} \times \mathbf{K}$ & \multicolumn{2}{|c|}{0.01} & & \multicolumn{2}{|c|}{0.03} & \multicolumn{2}{|r|}{0.77} & & \multicolumn{2}{|c|}{1.24} \\
\hline
\end{tabular}

Table.3 Estimation of available phosphorus and potassium in the soil after harvesting of annual chrysanthemum

\begin{tabular}{|c|c|c|c|c|c|c|c|c|c|c|}
\hline \multirow{3}{*}{ Treatments } & \multicolumn{10}{|c|}{ Phosphorus and potassium contents in soil after harvest } \\
\hline & \multicolumn{5}{|c|}{ Phosphorus (kg ha $\left.{ }^{-1}\right)$} & \multicolumn{5}{|c|}{ Potassium $\left(\mathrm{kg} \mathrm{ha}^{-1}\right)$} \\
\hline & $\mathbf{K}_{\mathbf{5 0}}$ & $\mathbf{K}_{100}$ & $\mathbf{K}_{150}$ & $\mathbf{K}_{200}$ & Mean & $\mathbf{K}_{\mathbf{5 0}}$ & $\mathbf{K}_{100}$ & $\mathbf{K}_{150}$ & $\mathbf{K}_{\mathbf{2 0 0}}$ & Mean \\
\hline $\mathbf{N}_{50}$ & 32.33 & 32.80 & 33.10 & 33.30 & 32.88 & 144.00 & 148.00 & 152.00 & 156.00 & $\mathbf{1 5 0 . 0 0}$ \\
\hline $\mathbf{N}_{100}$ & 33.40 & 33.70 & 34.20 & 34.60 & 33.98 & 160.00 & 163.00 & 165.00 & 170.00 & 164.50 \\
\hline $\mathbf{N}_{150}$ & 34.80 & 35.20 & 35.60 & 35.80 & 35.35 & 180.00 & 184.00 & 186.00 & 189.00 & 184.75 \\
\hline $\mathbf{N}_{200}$ & 36.00 & 36.30 & 36.65 & 36.90 & 36.46 & 198.00 & 202.00 & 206.00 & 208.00 & 203.50 \\
\hline \multirow[t]{2}{*}{ Mean } & 34.13 & 34.50 & 34.89 & 35.15 & 34.67 & 170.50 & 174.25 & 177.25 & 180.75 & 175.69 \\
\hline & \multicolumn{2}{|c|}{ SEm \pm} & & \multicolumn{2}{|c|}{ CD at $5 \%$} & \multicolumn{2}{|c|}{ SEm \pm} & & \multicolumn{2}{|c|}{ CD at $5 \%$} \\
\hline $\mathbf{N}$ & \multicolumn{2}{|c|}{1.12} & & \multicolumn{2}{|c|}{ NS } & \multicolumn{2}{|r|}{0.30} & & \multicolumn{2}{|c|}{088} \\
\hline $\mathbf{K}$ & \multicolumn{2}{|c|}{1.12} & & \multicolumn{2}{|c|}{ NS } & \multicolumn{2}{|r|}{0.30} & & \multicolumn{2}{|c|}{088} \\
\hline $\mathbf{N} \times \mathbf{K}$ & \multicolumn{2}{|c|}{1.24} & & \multicolumn{2}{|c|}{ NS } & \multicolumn{2}{|r|}{0.60} & & \multicolumn{2}{|c|}{1.16} \\
\hline
\end{tabular}


Table.4 Effect of different levels of nitrogen and potassium on nitrogen content in leaf, stem and flower of annual chrysanthemum

\begin{tabular}{|c|c|c|c|c|c|c|c|c|c|c|c|c|c|c|c|}
\hline \multirow{3}{*}{ Treatment } & \multicolumn{15}{|c|}{ Nitrogen content in plant parts } \\
\hline & \multicolumn{5}{|c|}{ Nitrogen content in leaf $(\%)$} & \multicolumn{5}{|c|}{ Nitrogen content in stem (\%) } & \multicolumn{5}{|c|}{ Nitrogen content in flower $(\%)$} \\
\hline & $\mathbf{K}_{50}$ & $K_{100}$ & $\mathrm{~K}_{150}$ & $\mathbf{K}_{200}$ & Mean & $\mathbf{K}_{\mathbf{5 0}}$ & $\mathbf{K}_{100}$ & $\mathbf{K}_{150}$ & $\mathbf{K}_{200}$ & Mean & $\mathbf{K}_{\mathbf{5 0}}$ & $\mathbf{K}_{100}$ & $\mathbf{K}_{150}$ & $\mathbf{K}_{200}$ & Mean \\
\hline $\mathbf{N}_{50}$ & 2.04 & 2.29 & 2.41 & 2.56 & 2.33 & 1.52 & 1.82 & 1.97 & 2.10 & 1.88 & 0.80 & 1.28 & 1.36 & 1.5 & 1.24 \\
\hline $\mathbf{N}_{100}$ & 2.61 & 2.73 & 2.84 & 2.99 & 2.79 & 2.24 & 2.41 & 2.56 & 2.64 & 2.46 & 1.69 & 1.81 & 1.96 & 1.98 & 1.86 \\
\hline $\mathbf{N}_{150}$ & 3.10 & 3.28 & 3.41 & 3.80 & 3.40 & 3.10 & 3.27 & 3.46 & 3.58 & 3.35 & 2.31 & 2.5 & 2.58 & 2.68 & 2.52 \\
\hline $\mathbf{N}_{200}$ & 3.50 & 3.74 & 3.85 & 3.97 & 3.77 & 3.28 & 3.41 & 3.50 & 3.60 & 3.45 & 2.55 & 2.65 & 2.74 & 2.82 & 2.69 \\
\hline \multirow[t]{2}{*}{ Mean } & 2.81 & 3.01 & 3.13 & 3.33 & 3.07 & 2.46 & 2.73 & 2.87 & 2.98 & 2.79 & 1.84 & 2.06 & 2.16 & 2.25 & 2.08 \\
\hline & \multicolumn{3}{|c|}{ SEm \pm} & \multicolumn{2}{|c|}{ CD at 5\% } & \multicolumn{2}{|c|}{ SEm \pm} & & \multicolumn{2}{|c|}{ CD at $5 \%$} & \multicolumn{3}{|c|}{ SEm \pm} & \multicolumn{2}{|c|}{ CD at 5\% } \\
\hline $\mathbf{N}$ & \multicolumn{3}{|c|}{0.021} & \multicolumn{2}{|c|}{0.063} & \multicolumn{2}{|c|}{0.068} & & \multicolumn{2}{|c|}{0.198} & \multicolumn{3}{|c|}{0.058} & \multicolumn{2}{|c|}{0.169} \\
\hline $\mathbf{K}$ & \multicolumn{3}{|c|}{0.021} & \multicolumn{2}{|c|}{0.063} & \multicolumn{2}{|c|}{0.068} & & \multicolumn{2}{|c|}{0.198} & \multicolumn{3}{|c|}{0.058} & \multicolumn{2}{|c|}{0.169} \\
\hline $\mathbf{N} \times \mathbf{K}$ & \multicolumn{2}{|c|}{0.040} & & \multicolumn{2}{|c|}{0.118} & \multicolumn{2}{|c|}{0.136} & & \multicolumn{2}{|c|}{0.377} & \multicolumn{2}{|r|}{0.116} & & \multicolumn{2}{|c|}{0.320} \\
\hline
\end{tabular}

Table.5 Effect of different levels of nitrogen and potassium on phosphorus content in leaf, stem and flower of annual chrysanthemum

\begin{tabular}{|c|c|c|c|c|c|c|c|c|c|c|c|c|c|c|c|}
\hline \multirow{3}{*}{ Treatment } & \multicolumn{15}{|c|}{ Phosphorus content in plant parts } \\
\hline & \multicolumn{5}{|c|}{ Phosphorus content in leaf $(\%)$} & \multicolumn{5}{|c|}{ Phosphorus content in stem (\%) } & \multicolumn{5}{|c|}{ Phosphorus content in flower (\%) } \\
\hline & $\mathbf{K}_{\mathbf{5 0}}$ & $\mathbf{K}_{100}$ & $K_{150}$ & $\mathbf{K}_{\mathbf{2 0 0}}$ & Mean & $\mathbf{K}_{\mathbf{5 0}}$ & $\mathbf{K}_{100}$ & $K_{150}$ & $\mathbf{K}_{200}$ & Mean & $\mathbf{K}_{\mathbf{5 0}}$ & $\mathbf{K}_{100}$ & $\mathbf{K}_{150}$ & $\mathbf{K}_{\mathbf{2 0 0}}$ & Mean \\
\hline $\mathbf{N}_{\mathbf{5 0}}$ & 0.18 & 0.24 & 0.26 & 0.28 & 0.24 & 0.27 & 0.31 & 0.33 & 0.36 & 0.32 & 0.31 & 0.34 & 0.37 & 0.39 & 0.35 \\
\hline $\mathbf{N}_{100}$ & 0.31 & 0.33 & 0.34 & 0.36 & 0.34 & 0.39 & 0.40 & 0.42 & 0.44 & 0.41 & 0.41 & 0.44 & 0.46 & 0.49 & 0.45 \\
\hline $\mathbf{N}_{150}$ & 0.39 & 0.40 & 0.44 & 0.45 & 0.42 & 0.47 & 0.47 & 0.49 & 0.48 & 0.48 & 0.51 & 0.54 & 0.57 & 0.59 & 0.55 \\
\hline $\mathbf{N}_{200}$ & 0.42 & 0.44 & 0.45 & 0.51 & 0.46 & 0.49 & 0.52 & 0.55 & 0.58 & 0.54 & 0.54 & 0.53 & 0.58 & 0.60 & 0.57 \\
\hline \multirow[t]{2}{*}{ Mean } & 0.33 & 0.36 & 0.37 & 0.40 & 0.36 & 0.41 & 0.43 & 0.45 & 0.47 & 0.44 & 0.44 & 0.47 & 0.50 & 0.52 & 0.48 \\
\hline & \multicolumn{2}{|c|}{ SEm \pm} & & \multicolumn{2}{|c|}{ CD at $5 \%$} & \multicolumn{2}{|c|}{ SEm \pm} & & \multicolumn{2}{|c|}{ CD at $5 \%$} & \multicolumn{3}{|c|}{ SEm \pm} & \multicolumn{2}{|c|}{ CD at $5 \%$} \\
\hline $\mathbf{N}$ & \multicolumn{2}{|c|}{0.009} & & \multicolumn{2}{|c|}{0.026} & \multicolumn{2}{|c|}{0.008} & & \multicolumn{2}{|c|}{0.024} & \multicolumn{2}{|r|}{0.009} & & \multicolumn{2}{|c|}{0.027} \\
\hline $\bar{K}$ & \multicolumn{2}{|c|}{0.009} & & \multicolumn{2}{|c|}{0.026} & \multicolumn{2}{|c|}{0.008} & & \multicolumn{2}{|c|}{0.024} & \multicolumn{2}{|r|}{0.009} & & \multicolumn{2}{|c|}{0.027} \\
\hline $\mathbf{N} \times \mathbf{K}$ & \multicolumn{2}{|c|}{0.017} & & \multicolumn{2}{|c|}{0.052} & \multicolumn{2}{|c|}{0.016} & & \multicolumn{2}{|c|}{0.048} & \multicolumn{2}{|r|}{0.018} & & \multicolumn{2}{|c|}{0.054} \\
\hline
\end{tabular}


Table.6 Effect of different levels of nitrogen and potassium on potassium content in leaf, stem and flower of annual chrysanthemum

\begin{tabular}{|c|c|c|c|c|c|c|c|c|c|c|c|c|c|c|c|}
\hline \multirow{3}{*}{ Treatment } & \multicolumn{15}{|c|}{ Potassium content in plant parts } \\
\hline & \multicolumn{5}{|c|}{ Potassium content in leaf $(\%)$} & \multicolumn{5}{|c|}{ Potassium content in stem (\%) } & \multicolumn{5}{|c|}{ Potassium content in flower $(\%)$} \\
\hline & $\mathbf{K}_{\mathbf{5 0}}$ & $\mathbf{K}_{100}$ & $\mathbf{K}_{150}$ & $\mathbf{K}_{\mathbf{2 0 0}}$ & Mean & $\mathbf{K}_{\mathbf{5 0}}$ & $\mathbf{K}_{100}$ & $K_{150}$ & $\mathbf{K}_{200}$ & Mean & $\mathbf{K}_{\mathbf{5 0}}$ & $\mathbf{K}_{100}$ & $\mathbf{K}_{150}$ & $\mathbf{K}_{200}$ & Mean \\
\hline $\mathbf{N}_{50}$ & 0.70 & 1.16 & 1.30 & 1.60 & 1.19 & 0.60 & 0.80 & 0.90 & 1.00 & 0.83 & 1.20 & 1.50 & 1.70 & 1.90 & 1.58 \\
\hline $\mathbf{N}_{100}$ & 1.60 & 1.90 & 2.20 & 2.30 & 2.00 & 1.10 & 1.30 & 1.40 & 1.40 & 1.37 & 2.10 & 2.30 & 2.40 & 2.50 & 2.33 \\
\hline $\mathbf{N}_{150}$ & 2.40 & 2.50 & 2.70 & 2.90 & 2.63 & 1.50 & 1.60 & 1.70 & 1.80 & 1.65 & 2.70 & 2.80 & 2.90 & 3.10 & 2.88 \\
\hline $\mathbf{N}_{200}$ & 3.00 & 3.20 & 3.50 & 3.60 & 3.33 & 1.90 & 2.30 & 2.40 & 2.60 & 2.30 & 3.20 & 3.28 & 3.60 & 3.70 & 3.45 \\
\hline \multirow[t]{2}{*}{ Mean } & 1.93 & 2.19 & 2.43 & 2.60 & 2.29 & 1.33 & 1.50 & 1.60 & 1.70 & 1.54 & 2.30 & 2.52 & 2.65 & 2.80 & 2.56 \\
\hline & \multicolumn{3}{|c|}{ SEm \pm} & \multicolumn{2}{|c|}{ CD at $5 \%$} & \multicolumn{2}{|c|}{ SEm \pm} & & \multicolumn{2}{|c|}{ CD at $5 \%$} & \multicolumn{3}{|c|}{ SEm \pm} & \multicolumn{2}{|c|}{ CD at $5 \%$} \\
\hline $\mathbf{N}$ & \multicolumn{3}{|c|}{0.084} & \multicolumn{2}{|c|}{0.245} & \multicolumn{2}{|c|}{0.062} & & \multicolumn{2}{|c|}{0.180} & \multicolumn{3}{|c|}{0.075} & \multicolumn{2}{|c|}{0.218} \\
\hline $\mathbf{K}$ & \multicolumn{3}{|c|}{0.084} & \multicolumn{2}{|c|}{0.245} & \multicolumn{2}{|c|}{0.062} & & \multicolumn{2}{|c|}{0.180} & \multicolumn{3}{|c|}{0.075} & \multicolumn{2}{|c|}{0.218} \\
\hline $\mathbf{N} \times \mathbf{K}$ & \multicolumn{2}{|r|}{0.160} & & \multicolumn{2}{|c|}{0.465} & \multicolumn{2}{|c|}{0.117} & & \multicolumn{2}{|c|}{0.342} & \multicolumn{3}{|c|}{0.142} & \multicolumn{2}{|c|}{0.413} \\
\hline
\end{tabular}

Table.7 Effect of different levels of nitrogen and potassium on number of flowers per plant, flower diameter and flower yield of Annual chrysanthemum

\begin{tabular}{|c|c|c|c|c|c|c|c|c|c|c|c|c|c|c|c|}
\hline \multirow{2}{*}{ Treatment } & \multicolumn{5}{|c|}{ Number of flowers per plant } & \multicolumn{5}{|c|}{ Flower diameter $(\mathrm{cm})$} & \multicolumn{5}{|c|}{ Flower yield per hectare $(q)$} \\
\hline & $K_{50}$ & $K_{100}$ & $K_{150}$ & $\mathbf{K}_{200}$ & Mean & $K_{50}$ & $K_{100}$ & $K_{150}$ & $\mathbf{K}_{200}$ & Mean & $K_{50}$ & $K_{100}$ & $K_{150}$ & $\mathbf{K}_{\mathbf{2 0 0}}$ & Mean \\
\hline $\mathrm{N}_{50}$ & 7.63 & 10.04 & 11.07 & 12.90 & 10.40 & 4.13 & 4.67 & 4.50 & 4.57 & 4.47 & 3.80 & 6.50 & 7.33 & 7.70 & 6.58 \\
\hline $\mathbf{N}_{100}$ & 10.27 & 11.20 & 13.90 & 14.90 & 12.57 & 5.77 & 5.90 & 5.50 & 5.48 & 5.66 & 8.10 & 8.40 & 9.48 & 9.90 & 8.97 \\
\hline $\mathrm{N}_{150}$ & 14.67 & 15.20 & 16.87 & 17.20 & 15.99 & 6.04 & 5.83 & 6.45 & 6.31 & 6.16 & 9.95 & 11.83 & 12.30 & 12.74 & 11.71 \\
\hline $\mathbf{N}_{200}$ & 18.50 & 20.00 & 28.00 & 22.00 & 22.13 & 5.00 & 6.63 & 7.83 & 6.90 & 6.59 & 13.50 & 14.00 & 25.25 & 20.75 & 18.38 \\
\hline \multirow[t]{2}{*}{ Mean } & 12.77 & 14.10 & 17.46 & 16.75 & 15.27 & 5.24 & 5.76 & 6.07 & 5.82 & 5.17 & 8.09 & 10.18 & 13.59 & 12.77 & 11.41 \\
\hline & \multicolumn{2}{|c|}{ SEm \pm} & & \multicolumn{2}{|c|}{ CD at $5 \%$} & \multicolumn{2}{|c|}{ SEm \pm} & & \multicolumn{2}{|c|}{ CD at $5 \%$} & \multicolumn{2}{|r|}{ SEm \pm} & & \multicolumn{2}{|c|}{ SEm \pm} \\
\hline $\mathbf{N}$ & \multicolumn{2}{|c|}{0.47} & & \multicolumn{2}{|c|}{1.34} & \multicolumn{2}{|r|}{0.06} & & \multicolumn{2}{|c|}{0.18} & \multicolumn{2}{|r|}{0.46} & & \multicolumn{2}{|c|}{1.35} \\
\hline $\bar{K}$ & \multicolumn{2}{|c|}{0.47} & & \multicolumn{2}{|c|}{1.34} & \multicolumn{2}{|r|}{0.06} & & \multicolumn{2}{|c|}{0.18} & \multicolumn{2}{|r|}{0.46} & & \multicolumn{2}{|c|}{1.35} \\
\hline $\mathbf{N} \times \mathbf{K}$ & \multicolumn{2}{|r|}{0.88} & & \multicolumn{2}{|c|}{2.57} & \multicolumn{2}{|r|}{0.12} & & \multicolumn{2}{|c|}{0.36} & \multicolumn{2}{|r|}{0.88} & & \multicolumn{2}{|c|}{2.56} \\
\hline
\end{tabular}


The data pertaining to nitrogen content in different plant parts of annual chrysanthemum was found significant with respect to the individual and interaction effects of nitrogen and potassium (Table 4). Application of nitrogen at the rate of $50 \mathrm{~kg} \mathrm{ha}^{-1}$ recorded significantly lowest nitrogen content available in leaf, stem and flower $(2.33,1.88$ and $1.24 \%$ respectively), whereas, significantly highest nitrogen content in leaf, stem and flower (3.77, 3.45 and $2.69 \%$ respectively) was observed by application of nitrogen at the rate of $200 \mathrm{~kg} \mathrm{ha}^{-1}$. Application of potassium at the rate of $50 \mathrm{~kg} \mathrm{ha}^{-1}$ recorded significantly lowest nitrogen content in leaf, stem and flower $(2.81,2.46$ and $1.84 \%$ respectively), whereas, significantly highest nitrogen content in leaf, stem and flower (3.33, 2.98 and $2.25 \%$ respectively) was recorded by application of potassium at the rate of $200 \mathrm{~kg}$ $\mathrm{ha}^{-1}$ followed by application of potassium at the rate of $150 \mathrm{~kg} \mathrm{ha}^{-1}$. Significant differences were observed in the inter action effect of nitrogen and potassium with respect to available nitrogen content in different plant parts. Significantly lowest nitrogen content in leaf, stem and flower $(2.04,1.52$ and $0.80 \%$ respectively) was observed by application of nitrogen and potassium each at the rate of 50 $\mathrm{kg} \mathrm{ha} \mathrm{ha}^{-1}$, whereas, significantly highest nitrogen content in leaf, stem and flower (3.97, 3.60 and $2.82 \%$ respectively) was observed by application of nitrogen and potassium each at the rate of $200 \mathrm{~kg} \mathrm{ha}^{-1}$ and was found at par with the application of nitrogen and potassium respectively the rate of 200 and $150 \mathrm{~kg} \mathrm{ha}^{-1}$.

The data pertaining to phosphorus content in different plant parts of annual chrysanthemum was found significant with respect to the individual and interaction effects of nitrogen and potassium (Table 5). Application of nitrogen at the rate of $50 \mathrm{~kg} \mathrm{ha}^{-1}$ recorded significantly lowest phosphorus content in leaf, stem and flower $(0.24,0.32$ and $0.35 \%$ respectively), whereas, significantly highest phosphorus content in leaf, stem and flower (0.46, 0.54 and $0.57 \%$ respectively) was observed by application of nitrogen at the rate of $200 \mathrm{~kg} \mathrm{ha}^{-1}$. Application of potassium at the rate of $50 \mathrm{~kg} \mathrm{ha}^{-1}$ recorded significantly lowest phosphorus content in leaf, stem and flower $(0.33,0.41$ and $0.44 \%$ respectively), whereas, significantly highest phosphorus content in leaf, stem and flower (0.40, 0.47 and $0.52 \%$ respectively) was recorded by application of potassium at the rate of $200 \mathrm{~kg}$ $\mathrm{ha}^{-1}$. Significant differences were observed in the inter action effect of nitrogen and potassium with respect to phosphorus content in leaf, stem and flower parts of the plant. Significantly lowest phosphorus content in leaf, stem and flower $(0.18,0.27$ and $0.31 \%$ respectively) was observed by application of nitrogen and potassium each at the rate of 50 $\mathrm{kg} \mathrm{ha}{ }^{-1}$, whereas, significantly highest phosphorus content in leaf, stem and flower (0.51, 0.58 and $0.60 \%$ respectively) was observed by application of nitrogen and potassium each at the rate of $200 \mathrm{~kg} \mathrm{ha}^{-1}$ which was at par with the application of nitrogen and potassium respectively at the rate of 200 and $150 \mathrm{~kg} \mathrm{ha}^{-1}$ (Table 6).

The data pertaining to potassium content in different plant parts of annual chrysanthemum was found significant with respect to the individual and interaction effects of nitrogen and potassium. Application of nitrogen at the rate of $50 \mathrm{~kg} \mathrm{ha}^{-1}$ recorded significantly lowest potassium content in the leaf, stem and flower $(0.19,0.83$ and $1.58 \%$ respectively), whereas, significantly highest potassium content in leaf, stem and flower (3.33, 2.30 and $3.45 \%$ respectively) was observed by application of nitrogen at the rate of $200 \mathrm{~kg}$ $\mathrm{ha}^{-1}$ followed by application of nitrogen at the rate of $150 \mathrm{~kg} \mathrm{ha}^{-1}$. Application of potassium at the rate of $50 \mathrm{~kg} \mathrm{ha}^{-1}$ recorded significantly lowest potassium content in leaf, stem and flower (1.93, 1.33 and $2.30 \%$ respectively), 
whereas, significantly highest potassium content in leaf, stem and flower $(2.60,1.70$ and $2.80 \%$ respectively) was recorded by application of potassium at the rate of $200 \mathrm{~kg}$ $\mathrm{ha}^{-1}$ and was found at par with the application of potassium at the rate of $150 \mathrm{~kg} \mathrm{ha}^{-1}$. Significant differences were observed in the inter action effect of nitrogen and potassium with respect to potassium content in different parts of the plant. Significantly lowest potassium content in leaf, stem and flower $(0.70, \quad 0.60$ and $1.20 \%$ respectively) was observed by application of nitrogen and potassium each at the rate of $50 \mathrm{~kg} \mathrm{ha}^{-1}$, whereas, significantly highest potassium content in leaf, stem and flower $(3.60,2.60$ and $3.70 \%$ respectively) was observed by application of nitrogen and potassium each at the rate of $200 \mathrm{~kg} \mathrm{ha}^{-1}$ which was found at par with the application of nitrogen and potassium respectively at the rate of 200 and $150 \mathrm{~kg} \mathrm{ha}^{-1}$. Based on the results obtained it could be conclude that $\mathrm{N}, \mathrm{P}$ and $\mathrm{K}$ contents of leaf, stem and flowers were increased with an increase in the dose of $\mathrm{N}$ and $\mathrm{K}$ applied from 50 to $200 \mathrm{~kg} \mathrm{ha}^{-1}$. The nitrogen content was found more in leaves than in stem and flower, whereas $\mathrm{P}$ and $\mathrm{K}$ contents were found more in flowers than in leaf and stem. Potassium content was observed low in stems than in leaves and flowers. The results have indicated that application of increased level of nitrogen and potassium increased the rate of photosynthesis and translocation of photo assimilates to different parts of the plant but more quantity of specific nutrients were supplied where there was a demand for a specific purpose. For example more content of potassium was diverted towards the development of reproductive parts where potassium plays a key role in the germination of pollen grains and development of pollen tube during fertilization and seed formation. The presence of more nitrogen content in the leaves helped to maintain the leaves in green colour for a prolonged period of time thereby enhancing the synthesis of amino acids, nucleotides and proteins thereby delaying the senescence of leaf. The continued supply of photo assimilates to the flowers maintained higher levels of phosphorus and potassium in flowers thereby extending the shelf life of flowers for a longer period of time. Similar kind of observations with regard to partitioning of nutrients to different plant parts was reported earlier by Woltz (1954), Kumar et al., (2003), Sharma and Singh (2007) and Kumar and Mishra (2011) in different flower crops.

The data pertaining to number of flowers per plant, flower diameter and yield per hectare in annual chrysanthemum was presented in Table 7. The data were found significant with respect to the individual and interaction effects of nitrogen and potassium. Significantly lowest number of flowers per plant (10.40), lowest flower diameter (4.47 $\mathrm{cm})$ and lowest flower yield per hectare $(6.58$ q) were observed by application of nitrogen at the rate of $50 \mathrm{~kg} \mathrm{ha}^{-1}$, whereas, application of nitrogen at the rate of $200 \mathrm{~kg} \mathrm{ha}^{-1}$ has recorded significantly highest number of flowers per plant (22.13), highest flower diameter $(6.59 \mathrm{~cm})$ and flower yield per hectare $(18.38$ q). Significantly lowest number of flowers per plant (12.77), lowest flower diameter $(5.24 \mathrm{~cm})$ and lowest flower yield per hectare $(8.09 \mathrm{q})$ were observed by application of potassium at the rate of $50 \mathrm{~kg}$ $\mathrm{ha}^{-1}$, whereas, application of potassium at the rate of $200 \mathrm{~kg} \mathrm{ha}^{-1}$ has recorded significantly highest number of flowers per plant (17.46). However, application of potassium at the rate of $150 \mathrm{~kg} \mathrm{ha}^{-1}$ has recorded significantly highest flower diameter $(6.07 \mathrm{~cm})$ and flower yield per hectare (13.59 q) which was found at par with the application of potassium at the rate of $200 \mathrm{~kg} \mathrm{ha}^{-1}$. Among the combination of doses, application of nitrogen and potassium each at the rate of $50 \mathrm{~kg} \mathrm{ha}^{-1}$ recorded significantly lowest number of 
flowers per plant (7.63), lowest flower diameter $(4.13 \mathrm{~cm})$ and lowest flower yield per hectare $(3.80 \mathrm{q})$, whereas, application of nitrogen and potassium at the rate of 200 and $150 \mathrm{~kg} \mathrm{ha}^{-1}$ respectively recorded significantly highest number of flowers per plant (28.00), highest flower diameter $(7.83 \mathrm{~cm})$ and highest flower yield per hectare (25.25 q). Based on the results obtained it could be concluded that application of higher levels of nitrogen and potassium nutrients might have enhanced the structural development as well as biochemical activities of the plant which helped in the diversion of more food reserves towards the developing flower buds which resulted in more number of flowers per plant. Further, it may be concluded that application of nitrogen and potassium at higher levels accelerated the photosynthetic activity by increasing the source size (number of branches and leaf area) and persistence of more number of green leaves for a longer period of time which helped in the accumulation of more photo assimilates and increased turgor potential in the plant tissue there by allowing the entry of more water into the cells thereby regulated the cell expansion in the floral tissue ultimately leading to an increase in the flower size in terms of flower diameter. Similar kind of results was reported earlier by Agrawal et al., (2002), Kishore et al., (2010) and Pal and Ghosh (2010) in African marigold. Joshi et $a l$. , (2013) reported an increase in the flower diameter with the application of nitrogen at the rate of $300 \mathrm{~kg} \mathrm{ha}^{-1}$ in chrysanthemum. Similar kind of result was noticed earlier by Sharma et al., (2006) with increased dose of nitrogen application at the rate of $200 \mathrm{~kg} \mathrm{ha}^{-1}$ in African marigold. The number of flowers per plant and per hectare increased with the application of graded doses of nitrogen and potassium in different combinations. The yield of flowers per plant and per hectare increased with the application of nitrogen mainly because of increased carbohydrate reserve for the development of floral primordia apart from the structural development of the plant. The present results were in confirmation with the earlier findings of Agrawal et al., (2002) Sharma et al., (2006) and Rajbeer and Jitendra (2009) in African marigold who obtained significantly higher yield with higher levels of nitrogen application.

\section{References}

Agrawal, S., Agrawal, N., Dixit, A. and Yadav, R.N. 2002. Effect of $\mathrm{N}$ and $\mathrm{K}_{2} \mathrm{O}$ in African marigold in Chattisgarh region. Journal of Ornamental Horticulture. 5(1): 86.

Chandana, K., and Dorajeerao, A.V.D. 2014. Effect of graded levels of nitrogen and phosphorus in gladiolus (Gladiolus grandiflorus L.) cv. White Prosperity. Plant Arhcives. 14(1): 143-150.

Chouhan, P., Vidhyasankar, M. and Rathore, V. 2014. Effect of NPK on physicochemical parameters of gladiolus (Gladiolus hybridus Hort.) cv. White Prosperity. International Journal of Scientific and Research Publications. 4: 12.

Jackson, M.L., 1967. Soil Chemical Analysis. Prentice Hall of India Pvt. Ltd., New Delhi. pp. 38-82.

Jackson, M.L., 1973. Soil chemical analysis. Prentice - Hall of India Private Limited, New Delhi.

Joshi, A.S., Varu, D.K., Barad, A.V. and Pathak, D.M. 2013. Performance of varieties and chemical fertilizers on growth and flowering in chrysanthemum. International Journal of Agricultural Sciences. 9(1): 182-88.

Kishore, G.R., Arya, J.K. and Ghalot, P.K. 2010. Effect of different levels of nitrogen, phosphorus and potassium on growth and flowering of African marigold cv. Pusa Narangi Gainda. Progressive Agriculture. 82(6): 941-45. 
Kumar, J., Chavhan, S.S. and Singh, D.V. 2003. Response of $\mathrm{N}$ and $\mathrm{P}$ fertilization on China aster. Journal of Ornamental Horticulture. 6(1): 82.

Kumar, R., and Misra, R.L. 2011. Studies on nitrogen application in combination with phosphorus or potassium on gladiolus cv. Jester Gold. Indian Journal of Horticulture. 68 (4): 535-39.

Pal, P., and Ghosh, P. 2010. Effect of different sources and levels of potassium on growth, flowering and yield of African marigold (Tagetes erecta Linn.) cv. 'Siracole'. Indian Journal of Natural Products and Resources. 1 (3): 371-75.

Panse, V.G., and Sukhatme, P.V. 1967. Statistical methods for agricultural workers. ICAR Publication, New Delhi. pp. 100-161.

Piper, C.S., 1966. Soil and plant analysis. Hans Publishers, Bombay.

Rajbeer, J.S., and Jitendra, K. 2009. Effect of nitrogen and pinching on growth and flowering in African marigold cv. Pusa Narangi Gainda. Annals of Horticulture. 2(2): 226-27.
Sharma, D.P., Manisha, P and Nishith, G. 2006. Influence of nitrogen, phosphorus and pinching on vegetative growth and floral attributes in African marigold (Tagetes erecta Linn.). Journal of Ornamental Horticulture. 9(1): 25-28.

Sharma, G., and Singh, P. 2007. Response of $\mathrm{N}, \mathrm{P}$ and $\mathrm{K}$ on vegetative growth, flowering and corm production in gladiolus under mango orchard. Journal of Ornamental Horticulture. 10(1): 5254.

Tandon, H.L.S., 1993. Agronomic evaluation and calibration of soil tests In: Proc. FADINAP Regional Workshop on Cooperation in Soil Testing for Asia and the Pacific, Bangkok (Thailand), 16-18 August. pp: 89-100.

Walkley, A., and Black, I.A. 1947. An examination of the degtjareff method for determining organic carbon in soils. Effect of variations in digestion conditions and of inorganic soil constituents. Soil Science. 63: 251-63.

Woltz, S.S., 1954. Studies on the nutritional requirements of gladiolus. Florida State Horticultural Society. Pp. 330-34.

\section{How to cite this article:}

Ravi Teja P., V. Vijaya Bhaskar and Subbaramamma, P. 2017. Influence of Graded Levels of Nitrogen and Potassium Combinations on the Flower Yield of Annual Chrysanthemum (Chrysanthemum coronarium L.). Int.J.Curr.Microbiol.App.Sci. 6(10): 1124-1134. doi: https://doi.org/10.20546/ijcmas.2017.610.136 